\title{
Benign Uterine Neoplasm
}

National Cancer Institute

\section{Source}

National Cancer Institute. Benign Uterine Neoplasm. NCI Thesaurus. Code C3609.

A non-metastasizing neoplasm that arises from the uterine corpus or the cervix.

Representative examples include leiomyoma, adenomyoma, and endocervical polyp. 